\title{
Най-хубавият вкус е да живееш и твориш в родината. Писма на художничката Бронка Гюрова-Алшех до Донка и Константин Константинови*
}

Abstract: Dushkova Mira, Naj-hubaviât vkus e da živeeš i tvoriš v rodinata. Pisma na hudožničkata Bronka Gûrova-Alšeh do Donka i Konstantin Konstantinovi (The Tastiest Flavour Is Living and Creating in the Motherland. Letters of the Artist Bronka Gyurova-Alcheh to Donka and Konstantin Konstantinov). "Poznańskie Studia Slawistyczne" 19. Poznań 2020. Publishing House of the Poznań Society for the Advancement of the Arts and Sciences, Adam Mickiewicz University, pp. 191-209. ISSN 2084-3011.

The current article presents five letters from the Bulgarian artist Bronka Gyurova-Alcheh written in the period 1959-1968, addressed to the writer Konstantin Konstantinov and his sister - the artist Donka Konstantinova. The letters were found in the personal archive of Konstantinov, and bring to light interesting facts of the life in Buenos Aires of Bronka Gyurova, who emigrated from Bulgaria in 1951 .

KeYwords: Bronka Gyurova-Alcheh; Konstantin Konstantinov; Donka Konstantinova; Argentina; $50 \mathrm{~s}-60$ s of $20^{\text {th }}$ century; emigration; painting

Преди няколко години, когато се запознах с архива на писателя Константин Константинов ${ }^{1}$ в Сливен, попаднах на писма от непознатата ми по това време Бронка Гюрова-Алшех. Тогава им хвърлих

${ }^{*}$ Статията е разработена по проект № 20-FNSE-01, финансиран от фонд „Научни изследвания“" на Русенския университет.

${ }^{1}$ Константин Константинов (1890-1970) е един от най-значимите български писатели и интелектуалци между двете световни войни, есеист, преводач от френски и руски, мемоарист. Автор на сборниците с разкази Към Близкия (1920), Любов (1925), Трета класа (1936), Ден по ден (1938), Седем часът заранта (1940), на романа Кръв (1933) и др. 
бегъл поглед, защото ми липсваше информация за нея. Коя беше тя? Какво я свързваше с Константин Константинов и с неговата сестра художничката Донка Константинова ${ }^{2}$ ? Как през $50^{- \text {-те }}$ години на XX век се беше озовала в далечния Буенос Айрес? Всички тези въпроси се таяха в мен през годините и си мислех, че все някога ще открия отговорите, още повече, че писмата дори за неизкушен читател бяха много интересни.

Бронка Гюрова (1910-1995) е родена в Шумен, но израства във Варна. В периода 1928-1932 година учи в Държавната художествена академия в София, специалност Живопис, при проф. Димитър Гюдженов (1891-1979). По време на следването си се сприятелява с Рада Поптошева, Васка Емануилова, Мара Георгиева и Стоян Венев (Константинова, 2010, 1). Значим момент от творческата ѝ биография е специализацията по илюстрация в Брюксел при проф. Минне (Константинова, 2010, 1). Членува в Дружеството на жените художнички, Дружеството на независимите художници, Дружеството „Съвременно изкуство“, Дружеството на новите художници.

Като член на сдруженията, през $30^{\text {-те }}$ и $40^{\text {-те }}$ години на XX век Бронка Гюрова участва в общите художествени изложби. Дори и като част от съвместните експозиции, нейните творби са откроявани от художествената критика. За участието ѝ в XIII обща художествената изложба през 1940 година Ангел Вълчанов пише: „Бронка Гюрова притежава свеж поглед и багрена новота. Пейзажите ѝ носят качествата на оригинално изживяно изкуство“ (Вълчанов, 1940, 206). Същият автор посочва характерното излъчване на творбите ѝ от XV обща художествена изложба: „Бронка Гюрова притежава дълбок усет за движението в мъртвата натура и светлината. Работите ѝ се раждат изведнъж и всичко в тях е споено от окото на дарен артист“ (Вълчанов, 1941, 488).

Пьрвата ѝ самостоятелна изложба е открита на 7 февруари 1943 г. в салона на зала „България“. Румяна Константинова пише, че художничката „събира многобройна публика, интересът към нейната

${ }^{2}$ Донка Константинова (1894-1973) - българска художничка, родена в Сливен. Учи живопис в Художествената академия в София при професорите Цено Тодоров, Стефан Иванов и Иван Мърквичка. През 1920 година открива съвместна изложба с Васил Захариев. Специализира в Париж (1925-1926). 
живопис е голям“ (Константинова, 2010, 1). При откриването на изложбата слово произнася Константин Константинов - писател с голям авторитет. В писмата си до брата и сестрата Бронка Гюрова си спомня именно тези негови думи.

Словото на Константинов е публикувано седмица по-късно във в. „Мир“. Той нарича Бронка Гюрова „един несъмнен художник“ и отговоря на въпроса какво носи нейното име за българската живопис:

Онова, което най-често липсва: истинска живопис. Т.е. един сигурен усет за троеличното единство: тон, обем и вещество; устойчива и безхитростна композиция; чувство за мяра и вкус; възпитано от най-възвишените традиции на ония образци, които са неоспоримата слава на френската живопис през двадесетия век. Един дъльг вътрешен път е изминат в няколко години: това личи в работите от Южна Франция - и тия от българското крайбрежие. Така художницата стига - би казал човек, като че без сама да съзнава - до най-ценното: тая учудваща и прелестна простота, която се превръща в синтез и която прави от нейното изкуство, едно изкуство за малцина. Тъкмо тая синтетична простота - хармонична, безбурна, постигната с лекотата на някакво упоение и озарена вътрешно - е богатството на тая изложба.

$[\ldots]$

Тая експресивна простота, трябва да се признае, рядко се съзира в повърхностните и припрени лутаници на българските художници. Толкова по-ценна е всяка нова, сполучена и сигурна стъпка. Бронка Гюрова е от малцината, които ни носят увереността за една богата утрешна българска живопис (Константинов, 1943).

От изброените по-горе дружества, в които участва Бронка Гюрова, най-голямо значение за съдбата ѝ има Дружеството на новите художници. То е създадено през 1931 година и съществува до 1944 година, когато се разпускат всички художествени дружества в страната (Димитрова, 2011, 12). Негови основатели са: Иван Фунев, Васка Емануилова, Драган Лозенски, Мара Георгиева, Борис Иванов, Вера Лукова, Стоян Сотиров, Стоян Венев, Петър Младенов. Сред членовете са и Бронка Гюрова, Елиезер Алшех (1908-1983)3 и Донка Константинова. Дружеството на новите художници организира няколко общи изложби, в които заедно участват и Бронка Гюрова, и Донка Константинова.

${ }^{3}$ Бронка Гюрова и Елиезер Алшех сключват брак през 1947. Елиезер Алшех е българин от еврейски произход. 
„Новите“ художници се стремят да модернизират изкуството, да бъдат „изразители на авангардното мислене“ (Доневска, 2011, 8). След смяната на политическия режим в България и особено след една изложба на български художници в Румъния (1948) започват обвиненията към Елиезер Алшех във формализъм (твърде остракираща за времето си квалификация), а на художника му е забранено да излага творбите си ${ }^{4}$. Румяна Константинова пише: „За да съхрани своите личностни ценности и да не измени на същността си на художник, той [Елиезер Алшех - бел моя, М. Д.] взема трудното решение да напусне България и да живее в емиграция. Това решение е огромно изпитание за Бронка Гюрова - нейните корени, близките ѝ, »новите«, признанието на публиката - всичко само за няколко месеца се превръща в скъп, но далечен спомен“ (Константинова, 2010, 2).

Под предлог, че иска да посети Израел, през 1951 година семейството, заедно с малката си дъщеря, напуска България. Първоначално живее в Милано, за да изчака входната виза, а от 1952 година се установява в Буенос Айрес (Аржентина). Художниците избират страната, тъй като още от $20^{-т е}$ години там живее сестрата на Елиезер Алшех ${ }^{5}$ Тук двамата остават до края на живота си. Елиезер Алшех се адаптира към новата среда, участва в много общи изложби, прави няколко самостоятелни, става популярен като българския художник в Аржентина, преподава в Националното училище за изящни изкуства „Мануел Белграно“ (1958-1973) ${ }^{6}$. За Бронка Гюрова процесът на приспособяване е по-дълъг. Известно време се занимава с приложна работа, преди отново да се върне към любимата си живопис ${ }^{7}$.

В последните години в България се наблюдават усилията на българските изкуствоведи да представят творчеството на Бронка Алшех.

${ }^{4}$ Е. Алшех е реабилитиран едва през 1975 г., когато е поканен от Съюза на българските художници да представи в изложба аржентинските си творби (http://www.bta.bg/ bg/c/BO/id/1874021; Новков, 2017, 309; Маринска, 1995, 62).

${ }^{5}$ Информацията е от интервю на дъщерята Деяна Алшех (http:/www.bta.bg/bg/c/ $\mathrm{BO} / \mathrm{id} / 1874021)$.

${ }^{6}$ Пак там.

${ }^{7}$ През 1955 г. представя самостоятелна изложба в галерия „Muller“ в Буенос Айрес (http://www.moreto.net/novini.php?n=419792); а през 1980 г. прави самостоятелна изложба в галерия „Руски“ (София). 
Организирани са няколко изложби: ретроспективна изложба „Елиезер Алшех. Бронка Гюрова-Алшех. 100 години от рождението на художника“ (Национална художествена галерия, ноем. 2008 - ян. 2009, куратори Пл. В. Петров, Р. Димова, Н. Ноева и Н. Гологанова); „Бронка Гюрова и нейният крьг“ - изложба, посветена на стогодишнината от рождението на художничката (Софийска градска художествена галерия, ян. - февр. 2010, куратори Р. Константинова и Сл. Иванова); представителна изложба, посветена на 75 години от самостоятелната ѝ изложба във Варна (Градска художествена галерия „Борис Георгиев“ - Варна, септ. 2018, куратор Д. Павлова; Художествена галерия „Елена Карамихайлова“ - Шумен, 2018; Художествена галерия - Добрич, ян. 2019).

С какво са важни днес писмата на Бронка Гюрова-Алшех? На първо място те дават ценна информация за нелекия живот на емигранта през $50^{\text {-те }}$ и $60^{\text {-те }}$ години на XX век. Писмата са свидетелство за търсенията ѝ в новата среда, но и за носталгията и за спомените от нейната България, която в мислите ѝ неизменно е там. Съхранени са спомени - едновременно радостни и в неизменна връзка с миналия живот, но и носещи болезненост и тъга - от първите десетилетия на века до 40-те години на XX век, когато Бронка Гюрова получава признанието на оригинален творец. Те са свидетелство, че художничката таи надежди отново да заживее в родината, което обаче не се случва.

Писмата ѝ носят колорита на аржентинската екзотика, те са своеобразно продължение на Писма от Южна Америка на Борис Шивачев ${ }^{8}$. Завладяват читателя с аржентинските блясък и нищета, с движението и вътрешната тишина, с описанието на ежедневния живот и с интензивната политическа обстановка. Интересни са и с цитирането на актуални заглавия (нови филми, нови пиеси), непознати за България по това време, но своевременно гледани в Аржентина. Докато в нашата страна от средата на $40^{-т е}$ на XX век западната култура е заклеймена като „упадъчна“, през 60-те години в Аржентина се

${ }^{8}$ Борис Шивачев (1902-1932) - български писател, критик, публицист. В периода 1920-1924 живее в Аржентина и Чили. Сборникът му с разкази Писма от Южна Америка е от 1932. 
налагат „,авангардните“ течения, култът към „новото“ или превъзнасянето на „младежкото“ (Саборидо, Привителио, 2013, 276)9.

Представените тук пет писма се публикуват за първи път. Те са написани ръкописно, с молив (между 2 и 7 страници), като са единствените оцелели от една по-голяма кореспонденция (както се подразбира при четенето им). Пьрвите четири писма са писани между 1959 и 1964 година, когато семейство Алшех все още не е посетило България. Последното писмо е от 1968, година след като художниците започват регулярно да посещават родината ${ }^{10}$.

Запазени са всички особености на правописа, граматиката и лексиката, без редакторско-коректорска намеса (особенно, В. Аирес / Б. Аирес, необикновенната и др.), извършени са корекции в пунктуацията, за да се избегнат двусмислици. Възстановените от мен думи, словосъчетания и изречения (малко на брой) са дадени в квадратни скоби []. Неразчетени остават и няколко изречения от долната част на страниците, в които се е изличило написаното.

Публикуваните писма на Бронка Алшех са важна част от творческата и житейската съдба на тази оригинална българска художничка, която - за жалост - все още остава недостатьчно позната на нашите съвременници. Тяхното публикуване е принос към едно бъдещо изследване на живота и творчеството на художничката ${ }^{11}$; знак за почит и към делото на Бронка Гюрова, но и към приятелството ѝ с българските интелектуалци - писателя Константин Константинов и художничката Донка Константинова.

\footnotetext{
${ }^{9}$ Според аржентинския историк Оскар Теран (1938-2008) през 60-те години на ХХ век в Аржентина се очертават четирите „души“ на периода: „душата на Бекет и абсурдът“, „душата на Кенеди и Съюзът за прогрес“, „душата на Ленън“ и „flower power“ [„Силата на цветята“ - англ.] и душата на Че Гевара и революционният бунт (цит. по: Саборидо, Привителио, 2013, 278).

${ }^{10}$ Бронка Алшех посещава периодично България от 1967 г. до края на живота си.

${ }^{11}$ Животьт и творчеството на Елиезер Алшех са значително по-добре систематизирани и проучени: вж.: Маринска, 1995; Алшех, Минчева, Русев, Константинова, Берон, Вутен, 2010; Филева, Труеба, Сивилов и др., 2018.
} 


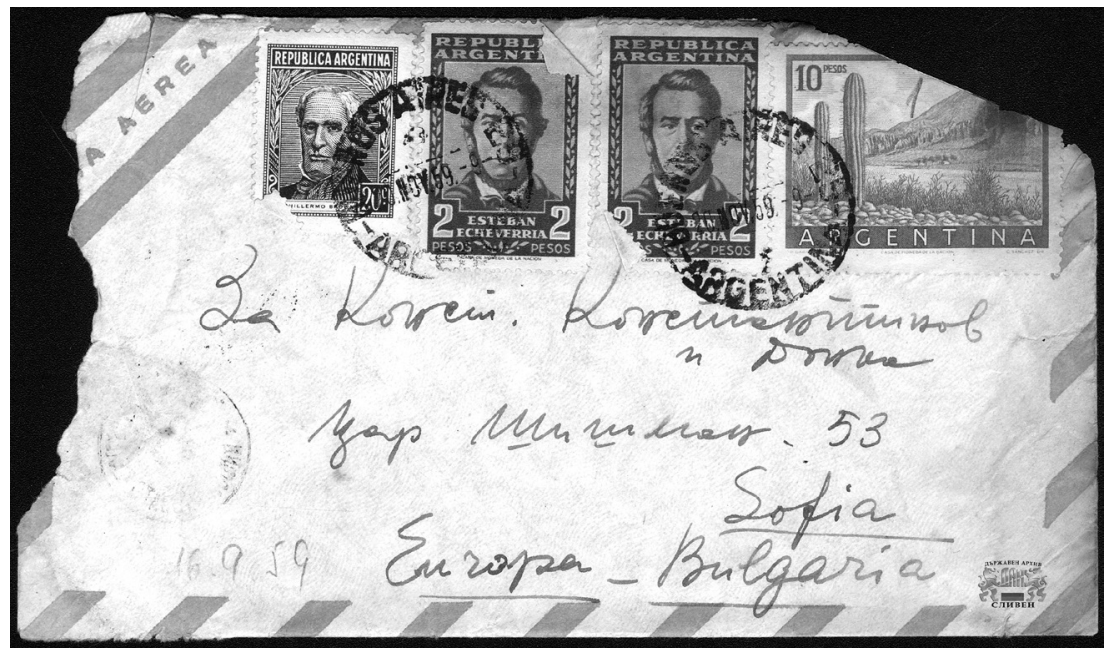

Фот. 1.

\section{Писма на Бронка Гюрова-Алшех до Донка и Константин Константинови}

1.

За Конст. Константинов

и Донка

Цар Шишман 53

Sofia

Europa-Bulgaria

$(16.9 .59)^{12}$

Br.Alcheh

B.Aires.

Други планове? Пьтуване ${ }^{13}$ Мечти, изглежда, неосъществими тук. Много години изминаха без да мръднем, без да се освежим. Живота ни е доста сив, особенно моя, защото с изкуството имам все по-малко вземане-даване - няма време,

${ }^{12}$ Пощенско клеймо - 22.11.59, София.

${ }^{13}$ Наличните листове от това писмо са без обръщение. Вероятно не е запазено цялото. 
няма спокойствие. Занимавам се все по-вече с текстилно рисуване и да отделям време и за живопис е наистина немислимо. Може би това лято ще излезем от В. Аирес и съм решила да рисувам, тъй както едно време - не портрет; да видим къде съм и какво мога. Всичко, което се вижда около нас, т.е. всичко младо прави един модернизъм ${ }^{14}$, който ни се струва е задънена улица или върха на един развой в изкуството, след което идва край, или връщане към началото. Всичко е разложено - няма цвят, няма форма, няма даже ритъм у някои, които се смятат най-добрите изразители на формализма. Няма красота. Сива безнадеждност и безизходност. Италианците са все още много силни, жизнени и има някакъв смисъл в тяхното бягане още по-далеч от модернизма от преди 2-3 години, който изглежда сега класицизъм. Алшех ${ }^{15}$ си върви по пътя и се възхищава от тези „шарлатани“, но аз намирам, че това, което виждаме в изкуството, е един напълно логичен резултат на необикновенната епоха, в която живеем. Ако по някакъв начин се сдобием с пари, мога да ви кажа плановете ни - Алшех ще отиде в Париж, а аз с Деянчето $^{16}$ там, в България ${ }^{17}$, но това няма да стане, защото ако се направи този план с молив в ръка, сметката трябва да се прекъсне наполовина, и освен това учението на Деяна става вече сериозно и не би могло да се прекъсне на сред годината, тъй като нашата ваканция е през вашата зима - ний вече я забравихме каква беше тя. Има една друга най-добре да я нарека моя фантазия, - да си дойдем тримата, но в такъв случай Алшех трябва да го вдигна от тук с динамит. Как ви изглежда това - можете ли да си го представите? Ще бъдем може би нещо като бели магарета? Не зная дали сте срещали Божето. Чрез нея, без да кажа нещо на Алшех, исках мнението на някои от колегите, специално за Алш[ех] дали е възможно неговото връщане и как биха го посрещнали. Божето ми отговори, че всичко би се уредило, но по-добре малко да се почака. Това ми даде кураж да кажа на Алшех, но колкото на мене ми се струва нормално да се върнем, толкова на него - невъзможно и нежелано. Както виждате, след толкова години, аз не съм се примирила. Понякога ми изглежда невъзможно да продължавам все тъй - не е лесно. До нищо реално [не] може да се стигне. Аз съм станала доста мъчна тежест и единственият изход е да съм непрекъснато много заета.

Около нас живота е все същия. Проблемите на вашия свят - стария, се отразяват тук и четем жадно всичко, с всички подробности и от всички мерници. Не зная дали ний познаваме по-малко от вас двамата съветски астронавти ${ }^{18}$. Имаше

${ }^{14}$ В годините след Втората световна война в Латинска Америка водещо е абстрактното изкуство, най-вече повлияно от САЩ (по Маринска, 1995, 54).

${ }^{15}$ В писмата си Бронка Гюрова нарича съпруга си с фамилното му име - Алшех.

${ }^{16}$ Деяна Алшех - дъщерята на художниците. Родена е през 1949 г. в София, архитект, понастоящем живее в Буенос Айрес. Заедно със съпруга си, архитекта Нестор Магариньос, проектира няколко сгради на Българския антарктически съюз на остров Линвингстън. Деяна Алшех се грижи за съхраняването на паметта за своите родители - през годините дава интервюта, предоставя картини, за да се направят изложби на двамата в България.

${ }^{17}$ Тук и по-долу думите, добавени от Бронка Алшех, са дадени в болд.

${ }^{18}$ Най-вероятно се имат предвид „бащата на съветската космонавтика“ Сергей 
много възторзи, много спорове и даже кавги по улиците и обществените превозни коли. Улиците са изпълнени с лозунги, протести и християнски мъдрости и благословии, които зорко следят да не изостанат в борбата ${ }^{19}$. Нашия „барбудо“ (брадат) комшия ${ }^{20}$ създава доста безпокойства на голяма част от южноамериканците, които до скоро се смятаха недосегаеми от войни и разни други напасти. Цял Б. Аирес плака и продължава да плаче на съв.[етския] филм „La balada del soldado“21, който от два месеца се показва тук. Аз още не съм го видяла, но няма да го изпусна. Видях един чудесен френски филм - „Moderato cantabile“22. Видях тази есен „Носорога“ на Йонеску ${ }^{23}$, с трупата на Луи Баро ${ }^{24}$. Интересен автор. И въпреки туй един приятел на Алшех от трудовашките години ${ }^{25}$, който беше тук

Павлович Корольов (1906-1966) и академик Мстислав Всеволодич Келдиш (1911-1978), рьководител на „Лунната програма“, свързани с пьрвия апарат (наричан Пьрви космически кораб, „Луна-1“ и „Мечта“), изстрелян от СССР в близост до Луната (2 ян. 1959).

${ }^{19}$ По същото време американците, в лицето на емигранта ракетостроител Вернер Фон Браун / Wernher von Braun (1912-1977), също разработват своите космически апарати „Пионер-1“, „Пионер-2“, „Пионер-3“. В периода 1957-1975 космическата надпревара за господство в космическите полети е много важна за двамата съперници в студената война - САЩ и СССР, в която преднина печелят руснаците.

${ }^{20}$ Въпреки че не може да се говори за директно съседство между Куба и Аржентина, най-вероятно брадатият комшия е алюзия с Фидел Кастро, който на 1 ян. 1959 г. довежда до край Кубинската революция.

Според Хорхе Саборидо и Лусиано де Привителио „победата на Фидел Кастро засилва антикомунистическите настроения. Разкриването на един план на Съветския съюз за господство в Латинска Америка прави много актуална идеята за »комунистическа опасност« и действията срещу нея, защото тя е »непосредствена«“" (Саборидо, Привителио, 2013, 245).

${ }^{21}$ Балада за войника (Баллада о солдате) - съветски филм от 1959 г. на режисьора Григорий Чухрай, заснет от „Мосфилм“.

${ }^{22}$ Moderato cantabile (1960) - френски филм с Жана Моро и Жан-Пол Белмондо, режисьор Питьр Брук, по едноименния роман на Маргьорит Дюрас.

${ }^{23}$ Има се предвид Носорози (1959) - пиеса от Йожен Йонеско.

${ }^{24}$ Жан-Луи Баро (1910-1994) - знаменит френски театрален и филмов актьор, режисьор, театрален директор, мим. Един от водещите актьори на „Комеди Франсез“ (1942-1946) и на френския театър. Споменатата трупа на Баро е създадена през 1959 година. В репертоара ѝ са включени постановки по творби на Пол Клодел (Златната глава), Самюъл Бекет ( $O$, щастливи дни), Йожен Йонеско и др.

${ }^{25}$ Във връзка със Закона за защита на нацията заради еврейския си произход Елиезер Алшех е въдворен в трудови лагери (Бов, Неделино, Трънска клисура - Сърбия, Ветрен, Белово, 1941-1944) - (Новков, 2017, 308). През 1944 г. е интерниран в родния си град Видин (Маринска, 1995, 38). Според Ружа Маринска „През тези тежки години Елиезер Алшех намира съчувствие и дружеска подкрепа в домовете на български интелектуалци, с които е свързан творчески и идейно. Ще спомена Хаджимишеви, Недкови, Акрабови, Константинови“ (Маринска, 1995, 38). 
за известно време (живее в Италия) ни каза - тук сте 150 години назад. Чувство, което и аз имах и продължавам да имам, макар и притъпено вече. Тангото напр. е също един голям, може да се каже нац. проблем. Говори се по радиото, устройват се кръгли маси, спори се. Аржент.[инците] са обезпокоени, защото тангото е в опасност - изражда се, качеството му е спаднало. Новите танга не могат да се сравняват с онези преди 30 години. Какво да се направи, се питат.

Буенос Аирес е все по-шумен, по-многолюден и по-уморяващ, затова късните разходки са все тъй приятни. Когато движението се пренася от едни улици на други, където са гъсто едно до друго големите кина, ресторанти много на мода, в които хората ядат, по-право - плюскат прави с лице към стената, където са невидимите заведения за наслади, за които се чете сутрин в черната хроника на вестн.[иците] сутрин, когато ослепителната светлина угасне и блесне ослепителното слънце или влажната, топла и мътна светлина на тукашната зима. Та в тези именно късни часове, понякога се разведряваме, разхождайки се по тихите разтоварени от движение улици, спирайки се по витрините, съзерцавайки чудесата на модата, книгите, платовете. Понякога се срещат чуждестранни морячета, забързани към пристанището с грамофонна плоча под мишница, в която отнасят една от онези страстни мелодии, които могат да се родят само тук, изпълнени [с гъсти думи - неразбираеми и очарователни за тях]. Ако знаеха колко са празни, колко еднакви и безсмислени. Но колко съм умна пък аз! Какво ли щях да кажа преди 30 години? Щях също тъй да съм обаяна от гъстия вкус на думи като corazon, и sangre и amor, perder, morder и т.н. ${ }^{26}$

Днес получих писмото Ви (9.X). Много се засрамих и много се зарадвах. Поне пишете нещо за двама ви. Мила Донке, много често мисля за тебе, за вашето у вас, за твоите грознички и вкусни кейкове и най-много за сладките приказки и дълги разговори - нещо, което остава незабравимо и незаменимо. Чакам скоро да получа втората част на книгата ${ }^{27}$. Радвам се, че работите. Ще свърша писмото, за да не се затрупа и забави пак. Прегръщам и целувам двама ви. Сърдечни поздрави от Алшех и Деяна.

Бях изпратила десетина каталога от изложбата на Алшех на колеги, и на вас също. Беше отдавна - дали са получени?

Горещи поздрави от двама ни на всички приятели - Бронка

${ }^{26}$ Corazón (исп.) - сърце; sangre (исп.) - кръв; amor (исп.) - любов; perder (исп.) изгубвам; morder (исп.) - хапя.

${ }^{27}$ Бронка Гюрова има предвид първата част на мемоарите Път през годините на Константин Константинов, излязла през юни 1959 г. Втората част е публикувана през февр. 1962 г. 
За Константинови цар Шишман 53

София

Europa - Bulgaria

Alcheh. Arcos 4039

B. Aires

23/X 1959.

\section{Мили}

Пак закъснях. Пак писах и писах на ум, и благодарих и разговарях... Сега да видим какво ще излезе из под калема. Каква хубава книга! С каква наслада я четох и се радвах на този чист хубав език, на всяка дума, пълна с съдържание и мярка, на хубавия разказ и на всичко разказано в нея. Такива книги трябват за опомняне на увлечените и забравилите (се) кое е истинско и кое не е и че едно нещо, колкото по-просто и непринудено се каже, толкова по-ценно е. Тъкмо противното ме дразнеше на толкова места в книгата $[\ldots]^{28}$. Жалко, защото книгата би могла да е сред много по-хубавите [...] книги. Но той е още млад, неизбистрен. Много въртене, много въздишки, много ентусиазъм, та не му стигат всичките приказки, които могат да се кажат за нещо. Всичко поднесено от Вас, мили бачо Коста ${ }^{29}$ (ли беше?) ми прилича на кристално, отлежало бяло вино. Отлежало в онези дълбочини, за които тъй хубаво пишете. Много съм разсъждавала, седейки тук сама, върху паметта, върху огромния товар, който носим, и който не чувствуваме, когато живота ни върви нормално. Аз бутам времето, обърната назад, където всичко ми изглежда хиляди пьти по-хубаво, отколкото е било - времето на изложбата ми напр. Първо, на каква хубава възраст бях - 32 години. [Палавата] първа младост беше преминала, бях стигнала до нещо, бях обиколена от хора, които обичах и които ме обичаха. На идване, когато минавахме Драгоман, на митницата ми взеха един пакет с всичките ми писма, изрезки от вестници и рисунки и акварели. Между изрезките от вестници беше и Вашето откриване на изложбата ми. Колко бих се зарадвала, ако ми пратехте препис от него. То беше толкова хубаво!

Четох на Деянчето нещо, именно, за дружбата с турчетата и още ще четем. За пръв път ми каза ах, че хубаво! Има ли още такива хубави неща да ми ги прочетеш? Иначе, все от любезност слуша, чете от немай къде, прави български диктовки $[\ldots . .$.$] . Сега чете Алшех и от време на време възклицава или коментира. Не-$

28 За съжаление в писмото не се чете с кой автор и с коя книга се прави сравнение, тъй като малки части от писмото са изрязани.

${ }^{29} \mathrm{~B}$ знак на почит към Константин Константинов се обръщат с бай Коста / бачо Коста и други по-млади негови съвременници - Александър Гиргинов (писател и драматург), Георги П. Арнаудов (публицист и журналист от Сливен), писателите Георги Мишев, Йордан Вълчев, Недялко Месечков, Станислав Сивриев и др. 
що[то], което не може да приеме, е Машев ${ }^{30}$. Този антисемит! Другия, романтичен образ на Машев - толкова оригинален с творчеството си и с стила си като човек му е съвсем чужд, а освен това има и лош спомен. От ония времена баща ми имаше една рисунка от Полянов ${ }^{31}$. Беше ми я оставил веднъж, като дойде в София, да я обрамча. Аз не успях да го направя, защото започнаха тревогите около нашето заминаване. Съдбата на тази рисунка ми е неизвестна. Може би е загинала при изкореняването на моя дом, който беше тъй краткотраен. Съжалявам, че не успях да опазя този хубав профил от младините му - майка ми и баща ми са живели до 1908 в София, където се е родил [Жорето]. Имаше много прилика. Брадата, разбира се, беше вече на мястото си. Не помня от кое време беше антологията ${ }^{32}$, която беше между книгите на баща ми, където за пръв път срещнах нещо от Вас (не помня какво), но помня рисунката (от кого ли беше? От теб ли, Донке?) ${ }^{33}$ на един хубавец с кривната широкопола шапка, чийто псевдоним „Душечка“. Вътре бяха и Гео Милев ${ }^{34}$, и Траянов, и Л. Стоянов и много други. Помня, че по това време (беше в първите години на гимназ.[ията]) направих и първия си (мисля единствен) литературен плагиат. Имаше един разказ „Бронка“, чийто автор не помня, и се говореше за някакви хризантеми и сняг. От там откраднах сигурно не буквално нещо и съчинението ми беше четено пред целия клас, като литературен образец. Не ми беше за пръв път, но тогава слушах примряла от страх и срам, защото смятах, че хубостта на съчинението се дължи именно на тези хризантеми. Излезе, че учителката е по-проста от мене и не е имала хабер ни от писателя, ни от антологията. Освен това, това беше по-рано, у дома имаше един сандък пълен с списания. Там беше „Българан“, „Смях““35, „Хиперион“, „Везни“, а може би и Вашето „Звено“36. Мисля, че имаше и „Листопад“, но не съм сигурна дали беше

${ }^{30}$ Става въпрос за художника Георги Машев (1887-1946), близък приятел на К. Константинов. Роден в Пазарджик, от 1906 до 1908 учи в Рисувалното училище в София, откъдето е изключен, а после учи и в Петербургската художествена академия и в специалния отдел по живопис в Брюксел. През 1930-1931 г. живее в Париж като свободен художник и осъществява изложби. Известен модерен художник през $20^{\text {-те }}$ и $30^{\text {-те }}$ години на XX век, повлиян най-вече от символизма.

${ }^{31}$ Вероятно - Димитър Полянов (1876-1953) - един от първите български пролетарски поети.

${ }^{32}$ Българска антология. Нашата поезия от Вазова насам. Съст. Д. Подвързачов и Д. Дебелянов (1910). Тук Константинов е най-младият български поет. Публикувани са стихотворенията му Еднодневка, Шут, Цариградски акварели, Майка, Утро, Тишина, Градът, Към братята. Стихотворенията са подписани със собственото му име, а не с известния псевдоним Душечка.

${ }_{33}^{33}$ Рисунката на Константинов е от Георги Машев.

${ }^{34}$ В Антологията на Подвързачов и Дебелянов не са включени стихове на Гео Милев.

35 „Българан“ (1904-1909) и „Смях“ (1911-1915) - популярни български хумористични списания.

${ }^{36}$ „Хиперион“ (1922-1931) , „Везни“ (1919-1922), „Звено“(1914) - едни от най-известните български модернистични списания, излизали в периода между двете световни войни. „Звено“ е редактирано от известния поет, преводач, журналист Димитьр 
списание или стихотворение свързано с [името на] Балабанов ${ }^{37}$. Аз се забавлявах много с този сандък, когато нашите бяха на фабриката ${ }^{38}$, която по онова време се помещаваше в един зимник. Всички заглавия и рисунки из тия списания бяха изписани от мене с пастели, разбира се, и четях без да разбирам особенно, но имената на всички писатели от това време така ми бяха известни.

Закъснях много да ви изпратя възторзите си. Прекъснах поради заболяване на Алшех и ето че минаха 2 седмици. До сега можех да получа отговор, искам толкова да знам как посрещнаха книгата Ви, как върви продажбата, и какви за условията сега за издаване на една книга? Еднократен хонорар ли се получава или имате процент върху продажбите? Вярваме, че самочувствието Ви е много променено и се радвам за това. Да знаете, че нищо няма по-хубав вкус от [това] да живееш и да твориш в родината. По същото време, когато получих вашето писмо, получих и за пръв път от Мара Георгиева ${ }^{39}$ едно мило, топло другарско писмо. Зарадвах се, но и няма да преувелича, ако ви кажа, че се разболях от мъка, която се надигна отново. Само думите „Можехте и вие да бъдете между нас“, стигат. Виждам, че живота на худ.[ожника] е много раздвижен и пълен. Ти, Донке, какво правиш. Нито една дума от тебе. Опита ли се да излагаш [в юбилейната изложба]. Какво прави Бенчо ${ }^{40}$, нищо не чувам за него. Преди известно време получихме един куп вестници. Надявам се, че вече е събран друг куп, от който от части поне следим и се радваме на всички големи и малки културни събития.

Нашия живот в онази далееена Аржентина, както си я представяте и която за нас е една ежедневна реалност, тече с същите грижи и безпокойства, както по целия свят. След толкова години свикнах да гледам по-обективно на всичко, което ме обикаля и да го преценявам по-добре. Латинците са приятни хора, имат безброй много форми да обещават, лъжат и отказват и да останат и в същото време очарователни, но могат и да проявят и жест на голямо доверие. Не са дребнави, което е голямо качество. Казват и пишат много, че страната много напредва, мъчат се да я спасяват, но от създаването на независима държава ${ }^{41}$, а пък и по-рано става горе-долу същото. Сменят се управление след управление от големи патриоти и реформатори ${ }^{42}$,

Подвързачов (1881-1937). Освен Константинов, печатат автори от неговия приятелски крьг - поетите Димчо Дебелянов (1887-1916) и Николай Лилиев (1885- 1960), писателят Георги Райчев (1882-1947) и др.

${ }^{37}$ Бронка Гюрова греши - литературно-художественото списание „Листопад“ (1913-1935) е с главен редактор Димитър Бабев.

${ }^{38}$ Във Варна бащата на Бронка Гюрова държи малка фабрика. Предполагам, че става въпрос за „Алекси Гюров““ - фабрика за тебешири, пластилин, бои, червен восък и др.

${ }^{39}$ Мара Георгиева (1905-1989) - известна българска скулпторка, близка приятелка на Бронка Гюрова, една от основателките на Дружеството на новите художници.

${ }^{40}$ Бенчо Обрешков (1899-1970) - български художник, един от най-големите български живописци, член на Дружеството на новите художници.

${ }^{41}$ Федерална република Аржентина е създадена през 1926 г.

${ }^{42}$ Семейство Алшех живее в Аржентина във време на политическа нестабилност непрекъснати политически промени, чести държавни преврати, противоборства и конфронтации (1955-1976). Основно обществото е разделено на перонисти (поддръжници 
които започват с кражби от неизчерпаемите богатства на страната и по-вечето от тях завършват живота си в чужбина - или избягали, или изгонени от политически противници. Въпреки постоянните стачки ${ }^{43}$ (според сведения от мама, стачкували ca 300 х. текстилци, което излезе верно, а освен тях безброй браншове, които се редуват), града не изгубва своя приятен и самодоволен вид. Най-голямото му очарование е в провинциалния облик и живот в много квартали, които са в съседство с оживени по североамерикански артерии и много паркове. Забавно е да вървиш из улиците, пълни с подобия на известни киноартистки, чорлави, по последна мода с опънати до пукване рокли на задниците, сложили изящните си крака в остроноси обувки с тънки като молив токчета. Момичетата са същите - отракани, сигурни в своите жестове, погледи, усмивки. Те са жени, южноамериканки, и всичко останало е по-малко важно. Мъжете се мъчат да ги следват - много по-малко интересни, но те също на 16-17 год. започват вече да ca novios - годеници. Малко по-настрана от това гъмжило са улиците, по които минават и се редуват от сутрин до вечер вехтошаря, точиларя, продавача на плодове, на мляко, на риба, на заклани зайци, на сладолед, на убитите по спортните игрища гълъби, продавача на плетени столове и кошници, който минава с натоварената като планина кола. Когато му омръзне, ляга на тротоара под сянката на някое дърво, слага си шапката на лицето и заспива. Кончето е свикнало и го чака търпеливо. Минават и продавачи на цветя и манифактуристи и какво ли не още. Има и друг Б. Аирес, който не познавам и нямам никакво желание, освен ако събера куража си и отида да рисувам. Това са кварталите „Basura“ (боклук $)^{44}$, „Karton““45, „Lata“ (тенеке), „Miseria“, също ${ }^{46}$, където къщите, облицовани с стари газени тенекии, също и покривите, и през лятото е адски горещо, квартала на кланниците и кой знае колко още безброй квартали от малки сиви къщички, които буквално се стопяват в безкрайното поле отвъд Б. Аирес.

Деянчето расте и има свои радости и грижи и аз с свито сърдце гледам как пуска коренчета. Какво ли ще стане с нас?

Най-после свършвам. Много забавих писмото, прощавайте. Чакам с нетърпение да пишете как беше посрещната книгата и какво става с останалите. За сега „Пътя през годините“ е все на масата - още не сме я допрегледали хубаво. Обещала съм я на 3-4 места.

Целувам ви горещо. Сърдечни поздрави от Алшех.

Бронка

на Хуан Перон, президент от 1946 до 1952, от 1952 до 1955; и от 1973 до 1974) и антиперонисти; много силна е и политическата роля на военните.

${ }^{43}$ През 1959 г. в Аржентина се наблюдава девалвация на националната валута с $65 \%$ и инфлация от $133 \%$. През първото полугодие има много стачки и засилване на репресиите от страна на властите (Саборидо, Привителио, 2013, 236).

${ }^{44}$ По-голямата част от испанските думи са преведени на български език от Бронка Алшех.

${ }^{45}$ Букв. картон, правилното изписване е „Cartón“ (исп.).

${ }^{46}$ Името villa „Miseria“ (квартал „Мизерия““ „Бедност“) е нарицателно, използвано за бидонвилите - жилища на бедняци в някои страни в Азия, Африка и Латинска Америка. 


\section{3.}

За К. Константинов

ул. Цар Шишман 53

Sofia

Bulgaria

B. Alcheh, Areos 4039

B. Aires

26/ IX.1961

Мили ми,

Как оставих да мине толкова време откакто получих писмото ви, не мога да си обясня. В суетни, бързане или пък апатия се изнизват месеци. След като получа дългоочаквано или вече неочаквано писмо, се усещам изведнъж много близко с там и съм толкова интензивно заета с мислене и разговори с вас, че писмото остава като по-късна фаза. Идва време, когато наистина трябва да седна да пиша, защото ми е необходимо да споделя, да се изкажа наистина и се започва търсене на време, място, настроение и т.н. Писмото ви стои в книгата, която чета, по-право - която не мога да чета и всеки пьт, когато го пипна, ви казвам по някоя любезна, извинителна думичка. И понеже вие не знаете нищо от туй, мога да си представя колко мълчаливи укори, колко мрачни заклинания сте теглили. Благодаря ви много, бачо Коста, за големия труд да ми изпратите „откриването“ на изложбата. И тъй както Вие сте се чудили - аз ли съм го написал туй, тъй и аз се чудих - аз ли бях туй. Също като че ли видях неочаквано свой портрет от младини. И разбира се, трябваше за не знам кой пьт да мисля какви подли изненади ни очакват в живота и колко малко можем да променим или пък не всеки може да промени или [да] се отклони от пътечката, която невидима пред нас ни очаква да я извървим. Чувствувам се особенно добре в този момент. Пиша в едно типично кафене на Б. Аирес - каквото може да се срещне на всеки ьгъл. Има едно отделение - ,para familias ${ }^{\text {“47 }}$, което е заградено от бара и мъжете, и в него се срещат двойки, майки с деца или сами жени, такива като мене. От две седмици Деянчето, която вече е Деяна, малко по-висока от мене, започна да се приготвя за встьпителен изпит в гимназия. Взема частни уроци далеч от къщи и понеже тук е пълно с реални и въображаеми опасности, трябва да я придружавам. В началото се ядосвах, но после открих, че очаквайки я, мога чудесно да използвам времето и да изпиша всички отлагани писма [...] [два реда не се четат].

Много време минава от едно писмо до друго, но малко неща се променят в живота ни. Питате какви планове кроим. Какво да ви кажа - аз кроя същите мисля с все по-вече право, колкото и да „не разбирам от политика“448. Колкото

${ }^{47}$ Para famillias / para las famillas (исп.) - за семейства; за семействата.

${ }^{48}$ През 1956 година в България се провежда Априлският пленум на Централния комитет на Българската комунистическа партия (ЦК на БКП). Смазването на Унгарското въстание от окт. 1956 г. води до затягане на мерките в България - „изключванията от партията, изобличенията в предателство и ревизионизъм, кампаниите в пресата срещу 
по-пораства Деяна, толкова повече мисля, че нейното място не е тук - да оставим мене. Не разбирам защо трябва да израсне в тази наситена с шумове, движение, престьпления атмосфера. Без екскурзии, без ходене на планина, без зимни радости, нито истински летни. Не казвам, че всичко е тъй сиво, както на пръв поглед изглежда. Може би в гимназията тя ще има много по-интересен живот, но за съжаление има доста сиво действие. През тази година тя се промени много срамежлива и решителна, както каза учителката ѝ, излезе, че е по-интелигентна, отколкото мислех, и доста постоянна и съзнателна в училищната си работа. Душа дава да може да излиза вън на полето, да плува или да се качва по дърветата. На рождени дни - класическия празник тук, вече не иска да ходи, защото нейните съученички вече танцуват. Някои имат новиос ${ }^{49}$ (12 години!) вече, но тя засега се държи тъй, като че ли това не се отнася до нея. Ходи тромаво, реже си косата сама почти като момче и забравя да си мие лицето сутрин. Тъй че, за кокетиране и дума да не става още. Веднаж видях, че по улицата край нас минава група момчета, водени от брата на една нейна приятелка. Нахакани и самоуверени, 13-14 год. момчета вървят като ергенати. Питам къде води Ектор тези момчета, Деянче? Тя се показа на вратата, изгледа ги критично и каза - buscan chicas - „търсят момичета“" и съвсем равнодушно си влезе.

От идущата година в каквото и училище да влезе, ще трябва да пътува много и тогава съвсем сбогом спокойствие. Синът на една моя позната ми каза, че няма защо да се безпокоя, защото на 13 или 14 години тя сигурно вече ще има novio (годеник) и ще има кой да я придружава. Никакви артистични наклонности не се показват до сега. Ако един ден се върнем там и ги покаже, бих била щастлива. Сега неочаквано за нас прави планове за учене, следване и реши да се опита да влезе в едно училище, което е много сериозно, смесено е и подготвя децата за научна работа. [три реда не се четат].

[Финалът на писмото не е запазен].

\section{4.}

24.VI.1964

Мили ми,

Колко време не сме си писали! Писмата с България изобщо се поразредиха, но аз не мисля по-малко за там. Не зная нищо за вас - как сте, защо не се обаждате? Божето, която ми разказваше за всичко, разреди също. Преди около два месеца ми писа дълго писмо-доклад. Пише най-много за семейството си, на което струва ми се тя управлява кормилото, потънала е в грижи и работа и ходене по планината, когато има време. От колегите от години никой не се обаждал - изобщо не ми е писал никой освен Мара Георгиева преди години. Дали се сеща още някой

»идеологическата диверсия« било в киното, било в литературата или изобразителните изкуства“ (Аврамов, 2011, 622).

${ }^{49}$ Nobio (исп.) - приятел, годеник. 
за нас? Изтече много време - всичко се е разместило и променило, а аз в моите мисли виждам всичко тъй, както го оставих. Ако някой ден намеря пътя за там, може би ще се чувствам съвсем чужда?

Исках да ви пиша по-рано, но както винаги се забавих. За там замина тукашния пълн.[омощен] министър г-н Георгиев ${ }^{50}$. Един много симпатичен човек (той, както и жена му), за които наистина съжалявам, че си отидоха, макар че се видяхме 2-3 пъти само. Всички хора, които имаха контакт с него, намират, че е много непосредствен и че има дар да се сближава с хората. Той научи тук чудесно испански. Понеже ме попита на кого искам да се обади, помислих разбира се за вас и за Божето. Исках да ви пратя и кафе, но беше неудобно. Пращам ви по едни чорапи, мисля, че такова нещо е винаги добре дошло. Много искам да ми пишете. Ний сме добре, да кажем, растем, стареем, суетим се, тъй се нижат дните. Днес [видях] в един тукашен вестник, че в Париж е представена операта „Дон Карлос“ с Гяуров ${ }^{51}$. Представлението се смята историческо. В същия вестник четем, че в Милано е поставена „Риенци“ от Vagner [Wagner] с Райна Кабаиванска ${ }^{52}$. Можете си представи колко много ме зарадва.

Г-н Георгиев замина [на 16] с параход, трябва да е вече там, ако не се забави някъде и може би вече сте се видели. Дано не ви разкаже нищо лошо за нас. С нетьрпение ще чакам известие от вас. Дано да сте добре - целувам ви горещо от трима ни -

Бронка.

Мила Донке, теб прегръщам отделно и искам да те видя.

5.

$\underline{\text { Via aérea }}$

За Константинов

Ул. Цар Шишман 53

Sofia

Bulgaria

[B.] Alcheh. Arers 1039. B. Aires

Честита Нова година!

Мили мои, умълчахте се и ний се умълчахме. Искам да ви пиша, но деня не идва. Много неща исках да споделя с вас, но го направих само мислено. Нашия живот

${ }^{50}$ Спас Георгиев (Спас Георгиев Спасов, 1906, Костенец, Ихтиманско - ?). Завършва университет в Москва. Пълномощен министър на България в Аржентина от 11 окт. 1961 до 16 ноем. 1964.

${ }^{51}$ Николай Гяуров (1929-2004) - световноизвестен български оперен певец, бас. Работил дълги години в Италия. Филип II от „Дон Карлос“ е една от знаковите му роли.

${ }^{52}$ Райна Кабаиванска (1934) - българска оперна певица, един от най-значимите сопранови гласове от втората половина на $\mathrm{XX}$ век. Голяма част от кариерата ѝ е свързана с Италия. Операта „Риенци“ е поставена в „Ла Скала“, диригент Херман Шерхен. 
след пътуването не може да се „намести“. Деяна следва с интерес, но има у нея и едно голямо недоволство, у мене също, но не мислим еднакво. Дано през идущата година не продължаваме тъй. Нищо не зная за вас. Сеньо не ми се обажда предполагам да ми са сърдити. Ще ми е много мъчно, ако е тъй. Но защо. Може да съм сбъркала нещо, но аз през цялото време [го / ги] обичам, както по-рано. Какво правите вие - здрави ли сте? Бехте ли миналата есен в Варна? Пишете ми няколко реда поне. Ако нямате желание, да се обади Сеньо, но аз все се надявам на едно писмо. Бъдете здрави и дано скоро пак се видим!

Прегръщам ви и ви пращам сърдечни поздрави от трима [ни].

Дек. 1968 год.

Бронка

\section{Благодарности}

Изказвам благодарност на преводачката Нева Мичева за насоките при разчитането на испанската лексика.

\section{Използвани архивни фондове}

Държавен архив - Сливен (България), Фонд 407К, оп. 1, а.е. 47.

[D"ržaven arhiv - Sliven (B"lgariâ), Fond 407K, op. 1, a.e. 47].

\section{Литература}

Аврамов, Д. (2011). Литература и изкуство. Мирогледно-естетически контексти. София: ИК Боян Пенев.

Алшех, Д., Минчева, К., Русев, С., Константинова, Р., Берон, П. В., Вутен, У. (на бълг. и англ., подгот.). (2010). Елиезер Алшех (1908-1983). Каталог. София: Изкуства и науки за изкуствата.

Вълчанов, А. (1940). [Тринадесета] ХІІІ обща художествена изложба. „Златорог“ XXI, № 4, с. 203-206.

Вълчанов, А. (1941). [Петнадесета] XV общахудожествена изложба. „Златорог“ XXII, № 10, с. 486-490.

Димитрова, Т. (2011). „Новите художници“ и властта (опит за пореден прочит на старите текстове). „Проблеми на изкуството“ № 4, с. 12-17.

Доневска, Б. (2011). „Новите“ в художествената критика. „Проблеми на изкуството“ № 4, с. 5-11.

Константинов, К. (1943). Изкуството на Бронка Гюрова. „Мир“ XLIX, 13 февр., № 12741 , с. 3 . 
Константинова, Р. (2010). Бронка Гюрова. Преоткриването. Каталог. [София]. https://doi.org/10.1515/9783110810608.

Маринска, Р. (1995). Елиезер Алщех. София: ЕТ Развигор Колев / Роро.

Новков, М. (2017). Елиезер, българинът. В: Новков, М. От Мърквичка до Минотавъра. Пловдив: Жанет-45, с. 307-322.

Саборидо, Х., Привителио, Л. (2013). Кратка история на Аржентина. София: Рива.

Филева, А., Труеба, Ал., Сивилов, Ал. et al. (на бълг., англ. и исп., съст.) (2018). Елиезер Алшех и ,естетика на безобразието “. София: Мултипринт ООД.

[Avramov, D. (2011). Literatura i izkustvo. Mirogledno-estetičeski konteksti. Sofiâ: IK Boân Penev.

Alšeh D., Minčeva K., Rusev S., Konstantinova R., Beron P. V., Vuten U. (na b"lg. i angl., podgot.). (2010). Eliezer Alšeh (1908-1983). Katalog. Sofiâ: Izkustva i nauki za izkustvata.

V"lčanov, A. (1940). [Trinadeseta] XIII obŝa hudožestvena izložba. „Zlatorog“ XXI, № 4, s. 203-206.

V"lčanov, A. (1941). [Petnadeseta] XV obŝa hudožestvena izložba. „Zlatorog“ XXII, № 10 , s. 486-490.

Dimitrova, T. (2011). „Novite hudožnici“ $i$ vlastta (opit za poreden pročit na starite tekstove). „Problemi na izkustvoto“ № 4, s. 12-17.

Donevska, B. (2011). „Novite“ $v$ hudožestvenata kritika. „Problemi na izkustvoto“ № 4, s. 5-11.

Konstantinov, K. (1943). Izkustvoto na Bronka Gûrova. „Mir“ XLIX, 13 fevr. № 12741, s. 3.

Konstantinova, R. (2010). Bronka Gûrova. Preotkrivaneto. Katalog. [Sofiâ]. https:// doi.org/10.1515/9783110810608.

Marinska, R. (1995). Eliezer Alšeh. Sofiâ: ET Razvigor Kolev/ Roro.

Novkov, M. (2017). Eliezer, b"lgarin"t. V: M. Novkov. Ot M"rkvička do Minotav"ra. Plovdiv: Žanet-45, s. 307-322.

Saborido, H., Privitelio, L. (2013). Kratka istoriâ na Aržentina. Sofiâ: Riva.

Fileva, A., Trueba, Al., Sivilov, Al. et al. (na b"lg. i angl. i isp., s"st.) (2018). Eliezer Alšeh $i$, estetikata na bezobrazieto “. Sofiâ: Multiprint OOD]. 